\title{
Trk: A Neuromodulator of Age-Specific Behavioral and Neurochemical Responses to Cocaine in Mice
}

\author{
Michelle Niculescu, ${ }^{1}$ Shane A. Perrine, ${ }^{1}$ Jonathan S. Miller, ${ }^{1}$ Michelle E. Ehrlich, ${ }^{2}$ and Ellen M. Unterwald ${ }^{1,3}$ \\ ${ }^{1}$ Deparment of Pharmacology and Center for Substance Abuse Research, Temple University School of Medicine, Philadelphia, Pennsylvania 19140, ${ }^{2}$ Farber \\ Institute for Neurosciences and Department of Neurology, Thomas Jefferson University College of Medicine, Philadelphia, Pennsylvania 19107, and \\ ${ }^{3}$ Laboratory of the Biology of Addictive Diseases, The Rockefeller University, New York, New York 10021
}

\begin{abstract}
Responses to psychostimulants vary with age, but the molecular etiologies of these differences are largely unknown. The goal of the present research was to identify age-specific behavioral and molecular adaptations to cocaine and to elucidate the mechanisms involved therein. Postweanling, periadolescent, and adult male CD-1 mice were exposed to cocaine $(20 \mathrm{mg} / \mathrm{kg})$ for $7 \mathrm{~d}$. The rewarding effects of cocaine were assessed, as were the response to a Trk antagonist and the regulation of dopamine and cAMP-regulated phosphoprotein, 32 $\mathrm{kDa}$ (DARPP-32). Cocaine was rewarding in both periadolescent and adult mice using a conditioned place preference procedure. In contrast, postweanling mice failed to demonstrate significant cocaine-induced place preference. Because components of the neurotrophin system including brain-derived neurotrophic factor and TrkB are developmentally regulated, their role in the age-specific effects of cocaine was determined using the Trk receptor antagonist K252a. Postweanling mice that received K252a before daily cocaine showed a significant place preference to the cocaine-paired environment that was not seen in the absence of K252a. DARPP-32 protein levels were significantly upregulated in the lateral region of the caudate-putamen exclusively in postweanling mice after chronic cocaine. Daily pretreatment with K252a attenuated the induction of DARPP-32 in the postweanling striatum. These data indicate that Trk neurotransmission plays a role in age-specific behavioral and molecular responses to cocaine and concurrently modulates DARPP-32 levels.
\end{abstract}

Key words: cocaine; DARPP-32; BDNF; TrkB; postweanling; striatum

\section{Introduction}

Exposure to psychostimulants often begins in childhood or adolescence because of the frequent onset of illicit drug use during this period (Fishman et al., 1997) or to the treatment of common childhood neuropsychiatric disorders such as attention deficit/ hyperactivity disorder. Responses to psychostimulants vary with age such that during adolescence and adulthood stimulants elicit euphoric responses, whereas they have been described as dysphoric by children (Rapoport et al., 1980). Most preclinical studies also indicate that the effects of stimulants increases with age (Cirulli and Laviola, 2000; Collins and Izenwasser, 2002; Tirelli et al., 2003). One model used to ascertain the rewarding properties of drugs in rodents is conditioned place preference (Bardo and Bevins, 2000). The general finding is that drug-induced place preference increases with age (Laviola et al., 1992, 1994; Tirelli et al., 2003; Schramm-Sapyta et al., 2004); however, there are conflicting reports (Campbell et al., 2000) and many studies do not include younger postweanling animals.

\footnotetext{
Received March 5, 2007; revised Dec. 13, 2007; accepted Dec. 13, 2007.

This work was supported in part by National Institutes of Health Grants NS41871 (M.E.E.) and DA07237 (E.M.U.). We gratefully acknowledge the contributions of Dr. Joseph A. Schroeder and Ms. Mary McCafferty for their technical expertise.

Correspondence should be addressed to Dr. Ellen M. Unterwald, Department of Pharmacology, Temple University School of Medicine, 3420 North Broad Street, Philadelphia, PA 19140. E-mail: ellen.unterwald@temple.edu.

M. E. Ehrlich's present address: Departments of Neurology and Pediatrics, Mount Sinai School of Medicine, 1 Gustave Levy Place, New York, NY 10029.

DOI:10.1523/JNEUROSCI.0988-07.2008

Copyright $\odot 2008$ Society for Neuroscience $\quad 0270-6474 / 08 / 281198-10 \$ 15.00 / 0$
}

Levels of several mediators of dopaminergic and neurotrophic neurotransmission peak during the postweanling and periadolescent periods in rodents and subsequently decline to adult levels (Ehrlich et al., 1990; Yurek et al., 1998; Costantini et al., 1999; Andersen and Teicher, 2000; Spear, 2000). This developmental window represents a period of increased plasticity of the brain (for review, see Laviola et al., 1999). Intrinsic alterations in modulators of neurotrophic and dopaminergic activity may contribute to the fact that younger animals are affected differentially by psychostimulants compared with their adult counterparts (Andersen, 2002; Ehrlich et al., 2002; Fukui et al., 2003).

Previous studies have demonstrated that neurotrophins can alter behavioral responses to cocaine. Brain-derived neurotrophic factor (BDNF) infusions into the nucleus accumbens or ventral tegmental area augment behavioral sensitization and conditioned reinforcement to cocaine in adult rats (Horger et al., 1999; Lu et al., 2004; Graham et al., 2007), likely at least in part by enhancing striatal dopamine release (Altar et al., 1992). Cocaine directly increases dopaminergic neurotransmission (DiChiara and Imperato, 1988) and therefore protein kinase A (PKA) activity (Nishi et al., 2000). Increased PKA activity results in phosphorylation of dopamine- and cAMP-regulated phosphoprotein of $32 \mathrm{kDa}$ (DARPP-32) at the $\mathrm{Thr}^{34}$ site (Hemmings et al., 1984), and DARPP-32 and its phosphorylation at the $\mathrm{Thr}^{34}$ site are required for the development of cocaine place preference in adult mice (Zachariou et al., 2002, 2006). Whereas cocaine induces phosphorylation of DARPP-32 in the adult, this does not occur in 
striatal slices from younger mice (Fukui et al., 2003). Levels of total DARPP-32 are unchanged after cocaine exposure in adults (Bibb et al., 2001; Ehrlich et al., 2002). Of note, however, DARPP-32 levels are regulated by endogenous BDNF and its receptor TrkB during development (Ivkovic et al., 1997).

The goal of the present study was to identify age-specific behavioral effects of cocaine and to elucidate potential molecular mediators thereof. The rewarding effects of cocaine were measured in mice of different ages using a conditioned place preference procedure. The role of Trk neurotransmission was investigated using a Trk receptor antagonist, K252a. In addition, agespecific and regional regulation of DARPP-32 mRNA and protein during cocaine exposure was investigated.

\section{Materials and Methods}

Animals. Male CD-1 mice were obtained from Charles River Laboratories (Wilmington, MA). Mice were weaned from the dam on postnatal day 21 . Mice were housed four per plastic cage $(28 \times 20 \times 14 \mathrm{~cm})$ in a temperature- $\left(21 \pm 1^{\circ} \mathrm{C}\right)$ and relative humidity $(40 \pm 10 \%)$-controlled room on a $12 \mathrm{~h}$ light/dark cycle (lights on at 7:00 A.M.). Animals were housed for $5 \mathrm{~d}$ before being tested during which time they were weighed and handled daily. Animals had ad libitum access to standard laboratory chow and tap water except during behavioral testing sessions. Postweanling mice were $24 \mathrm{~d}$ old, periadolescent mice were $33 \mathrm{~d}$ old, and adult mice were $60 \mathrm{~d}$ old on the first day of drug administration. All experiments were conducted in accordance with the National Institutes of Health Guidelines for the Care and Use of Laboratory Animals and with an approved protocol from Temple University Institutional Animal Care and Use Committee.

Drugs. Cocaine $\mathrm{HCl}$ was generously supplied by the National Institute of Drug Abuse and was dissolved in sterile saline $(0.9 \% \mathrm{NaCl})$. Cocaine and saline were administered intraperitoneally in a volume of $3 \mathrm{ml} / \mathrm{kg}$ body weight. K252a (Alomone Labs, Jerusalem, Israel) was dissolved in vehicle consisting of $75 \%$ sterile saline/25\% dimethyl sulfoxide. K252a and its vehicle were administered intracerebroventricularly in a volume of $3 \mu$ l delivered over $1 \mathrm{~min}$.

Surgery. Postweanling mice underwent surgery at $21 \mathrm{~d}$ of age. They were anesthetized with a mixture of Telazol $(10 \mathrm{mg} / \mathrm{ml})$ (Elkins-Sinn, Cherry Hill, NJ) and Xylazine ( $3 \mathrm{mg} / \mathrm{ml}$ ) (Burns Vet, Westebury, NY) (4 $\mathrm{ml} / \mathrm{kg}$, i.p.) and placed in a Kopf (Tujunga, CA) stereotaxic instrument adjusted for mice. A self-made polyethylene 10/20 cannula (BectonDickinson, Parsippany, NJ) was inserted into the lateral ventricle. Coordinates were as follows from bregma: anteroposterior -0.5 , mediolateral 1.0, and dorsoventral -2.0 (Paxinos and Franklin, 2001). The cannula was secured to the skull by a small screw and dental cement. All mice were allowed $3 \mathrm{~d}$ to recover before experimentation began. Verification of cannula placement was performed at the end of the study by gross visual inspection during brain dissections.

Drug administration and behavioral testing. Postweanling, periadolescent and adult mice were tested for cocaine-induced conditioned place preference. The conditioned place preference chambers were rectangular in shape $(45 \times 20 \times 20 \mathrm{~cm})$ and consisted of two compartments, separated by a removable door. One compartment had black walls with a sandpaper floor whereas the other had white walls with black vertical stripes and a smooth floor. An unbiased, counterbalanced design with two conditioning sessions per day was used. Each mouse received a saline ( $3 \mathrm{ml} / \mathrm{kg}$, i.p.) injection in the morning between 8 and 9:00 A.M. and was randomly assigned to one side of the chamber. In the afternoon between 4:00 and 5:00 P.M., mice were injected with cocaine $(20 \mathrm{mg} / \mathrm{kg}$, i.p.) or saline ( $3 \mathrm{ml} / \mathrm{kg}$, i.p.) and confined to the opposite side of the chamber. Conditioning sessions lasted for $30 \mathrm{~min}$ and began immediately after cocaine or saline injections. Conditioning sessions began on postnatal day 24,33 , and 60 , respectively, for postweanling, periadolescent and adult mice and was repeated daily for $7 \mathrm{~d}$.

Postweanling mice assigned to the Trk receptor antagonist study were pretreated with either K252a (48 ng/3 $\mu$ l, i.c.v.) (Rattiner et al., 2004) or vehicle ( $3 \mu$ l, i.c.v.) in their home cages $30 \mathrm{~min}$ before the daily afternoon conditioning sessions. On the test day (day 8), place preference was determined at $\sim 12: 00$ noon. Mice were drug-free and had access to both sides of the chamber. The time spent in each compartment was recorded over a 30 min test session. The difference between the time spent on the afternoon conditioned side (cocaine or saline) versus the time spent on the morning conditioned side (saline) was calculated in seconds. Group differences in preference scores were analyzed by two-way ANOVAs with either age and treatment or pretreatment and treatment factors (Prism; GraphPad Software, San Diego, CA). Bonferroni's post-test comparisons were performed with a significant ANOVA. In addition, preference scores were compared with zero using a one-sample Student's $t$ test (GraphPad InStat). The null hypothesis was rejected when $p<0.05$.

Locomotor activity was monitored simultaneously during conditioning on the first and last afternoon conditioning sessions (days 1 and 7) using Digiscan activity monitors (Accuscan, Columbus, $\mathrm{OH}$ ). The monitors are equipped with 16 infrared light emitters and detectors. The number of times the photo beams was broken and pattern of beam breaks was recorded by a computer. Activity was monitored for $30 \mathrm{~min}$ after cocaine or saline injection, and mean total activity counts were calculated. Group mean activity counts were compared by ANOVA (GraphPad Prism).

In situ hybridization. Brains were obtained $18 \mathrm{~h}$ after the final injection. Mice were lightly anesthetized with $\mathrm{CO}_{2}$ and rapidly decapitated. Brains were removed and flash frozen in isopentane cooled to $-30^{\circ} \mathrm{C}$ and stored at $-80^{\circ} \mathrm{C}$. Frozen mouse brains were cut into $16 \mu \mathrm{m}$ sections on a cryostat at $-18^{\circ} \mathrm{C}$ from $1.5 \mathrm{~mm}$ anterior to $0.5 \mathrm{~mm}$ posterior of bregma. Sections were thaw mounted onto Plus slides (Fischer Scientific, Pittsburgh, PA) and stored at $-80^{\circ} \mathrm{C}$ until labeled. Sections were thawed under a stream of cool air, fixed in 3\% paraformaldehyde, washed with $2 \times$ SSC and treated in $0.1 \mathrm{~m}$ triethanolamine containing $0.25 \%$ acetic anhydride. Slides were then dehydrated in ethanol and allowed to air dry before hybridization. The following oligo DNA sequence directed against the DARPP-32 gene transcript (GenBank accession number NM144828) was synthesized by Biosynthesis (Lewisville, TX): 5'TTCTGGGGAGCACTTCCTCCTCCTGGGAAGARACAGGGCTCTCTGAGCTT $3^{\prime}$. Oligonucleotides were 3 'labeled with $\operatorname{dATP} \alpha\left[{ }^{35} \mathrm{~S}\right]$ using terminal deoxynucleotidyl transferase (Roche, Indianapolis, IN). The labeled probe was purified by phenol/chloroform extraction, precipitated in ethanol, and reconstituted in water. A probe mixture containing labeled oligonucleotide $(1 \times 106 \mathrm{cpm} / 50 \mu \mathrm{l}), 10 \mathrm{mg} / \mathrm{ml}$ salmon sperm, and $0.77 \mathrm{~g} / \mathrm{ml}$ DTT in hybridization buffer was prepared and incubated at $40^{\circ} \mathrm{C}$ for $30 \mathrm{~min}$ before hybridization. Hybridization was allowed to occur overnight at $37^{\circ} \mathrm{C}$. After hybridization, the slides were dehydrated and exposed to $\mathrm{x}$-ray film ( $\beta \max$ Hyperfilm; GE Healthcare Bio-Sciences, Piscataway, NJ) for 1 week. Autoradiograms were analyzed for optical density using an AISTM/C Analytical Imaging System (InterFocus Imaging, Linton, UK) calibrated against autoradiographic $\left[{ }^{14} \mathrm{C}\right]$ microscales (GE Healthcare Bio-Sciences) included with each film. Optical densities were assessed in brain sections from rostral (approximately +1.5 to $+1.1 \mathrm{~mm}$ rostral to bregma) and caudal $(+0.4$ to $-0.10 \mathrm{~mm}$ ) striatum (Paxinos and Franklin, 2001), and the caudate-putamen was bisected vertically for lateral and medial readings. Measurements from three sections per brain region per animal were averaged. Mean optical density measurements of DARPP-32 mRNA in the nucleus accumbens and the rostral and caudal caudate-putamen were expressed as the percentage difference of each cocaine-treated group versus their saline age-matched control. Means from saline and cocaine treated animals of each age were compared by a Student's $t$ test (GraphPad Software). A $p$ value of $<0.05$ was considered statistically significant.

Northern blots. Brain tissue samples were obtained $18 \mathrm{~h}$ after the final injection. Mice were lightly anesthetized with $\mathrm{CO}_{2}$ and then decapitated. Brains were removed and the nucleus accumbens, and lateral and medial aspects of the rostral and caudal caudate-putamen were dissected on ice using a coronal matrix and stored at $-80^{\circ} \mathrm{C}$. RNA was extracted from the tissue samples with TRIzol LS Reagent (Invitrogen, Carlsbad, CA). Extracted RNA was stored in DEPC $\mathrm{H}_{2} \mathrm{O}$ at $-80^{\circ} \mathrm{C}$ until assayed. RNA (1-5 $\mu \mathrm{g})$ extracts were electrophoresed through a $2.4 \%$ agarose, $2 \%$ formaldehyde gel and then transferred to positively charged nylon membranes (Ambion, Austin, TX) using 20× SSC. Membranes were blocked in 
ULTRAhyb hybridization buffer (Ambion) for $2 \mathrm{~h}$ and then the $3^{\prime}$-end $\left[{ }^{32} \mathrm{P}\right] \mathrm{dATP}$ antisense oligonucleotide probes for DARPP-32 and actin (Ambion) were added. Hybridization was performed overnight at $42^{\circ} \mathrm{C}$. Membranes were washed at $42^{\circ} \mathrm{C}$ down to $2 \times$ SSC, $0.1 \%$ SDS before exposure to PhosphorImager (GE Healthcare Bio-Sciences). Specific bands were quantified using densitometry (Fujifilm, Valhalla, NY). Optical density measurements of DARPP-32 mRNA were expressed as the percentage difference of each cocaine-treated group versus their saline age-matched control. Means from saline and cocaine treated animals of each age were compared by a Student's $t$ test (GraphPad Software). A $p$ value of $<0.05$ was considered statistically significant.

Western blotting. Protein was simultaneously extracted from the same samples of nucleus accumbens, and lateral and medial aspects of the rostral and caudal caudate-putamen as described in the preceding paragraph with TRIzol LS reagent (Invitrogen). Protein extracts were stored in $1 \%$ SDS at $-80^{\circ} \mathrm{C}$ until assayed. Protein extracts $(2.5-5 \mu \mathrm{g})$ were then subjected to SDS-PAGE (10\% Tris-HCl Bio-Rad Ready Gels; Bio-Rad, Hercules, CA) and transferred to nitrocellulose membranes. Membranes were blocked for $1 \mathrm{~h}$ in blocking buffer (5\% nonfat dry milk in Tween 20 -TBS) and then incubated in anti-DARPP-32 (1:10,000; Millipore, Temecula, CA) or anti- $\beta$-tubulin (1:10,000; Sigma, St. Louis, MO). After washes, the membranes were incubated with secondary antibody conjugated to horseradish peroxidase (1:5000; Vector Laboratories, Burlingame, CA) for $1 \mathrm{~h}$. Immunoreactivity was detected by enhanced chemiluminescence using Supersignal West Pico chemiluminescent substrate (Pierce Chemical, Rockford, IL). Specific bands were quantified using densitometry (Fujifilm).

For the measurement of phospho-DARPP-32, animals were killed by decapitation $15 \mathrm{~min}$ after an acute injection of saline or cocaine, 20 $\mathrm{mg} / \mathrm{kg}$, and brains rapidly removed. Brains were placed in ice-cold PBS followed by rapid dissection of the caudate-putamen on ice. Tissue samples were immediately homogenized in 1\% SDS containing phosphatase inhibitors (Phosphatase Inhibitor Mixture II; Sigma), boiled for $5 \mathrm{~min}$, and stored at $-80^{\circ} \mathrm{C}$ until assayed. Protein extracts $(40 \mu \mathrm{g})$ were subjected to SDS-PAGE and transferred to nitrocellulose membranes as described above. Membranes were probed with antibodies to phosphoThr ${ }^{34}$-DARPP-32 (1:1000; PhosphoSolutions, Aurora, CO), phosphoThr ${ }^{75}$-DARPP-32 (1:1000; PhosphoSolutions), total DARPP-32 (1:10,000; PhosphoSolutions), and $\beta$-tubulin (1:20,000; Sigma). Optical densities of the proteins of interest were expressed as a ratio to tubulin and group means compared by a two-way ANOVA with age and treatment factors, followed by Bonferroni's post-tests.

\section{Results}

Effect of age on cocaine-induced conditioned place preference Postweanling, periadolescent and adult mice underwent a cocaine conditioning procedure for $7 \mathrm{~d}$ as described above using an unbiased, twice-daily conditioning paradigm. On day 8 , preference/aversion was determined in a drug-free state by measuring the time spent in both sides of the chamber. Two-way ANOVA revealed a significant effect of treatment (treatment, $F_{(1,49)}=$ $7.42, p<001$; age, $F_{(2,49)}=0.06, p>0.05$; interaction, $F_{(2,49)}=$ $0.97, p>0.05)$. Adult and periadolescent mice conditioned with cocaine showed a significantly greater place preference for the cocaine-paired side compared with control animals receiving saline in both compartments (Fig. 1$)(p<0.05)$. In contrast, postweanling mice conditioned with cocaine in a similar manner did not show a significant place preference to the cocaine-paired side and were not different from those receiving saline in both chambers $(p>0.05)$. We conclude using this conditioned place preference paradigm and drug dose that cocaine was not rewarding to postweanling mice, although it was to periadolescent and adult mice.

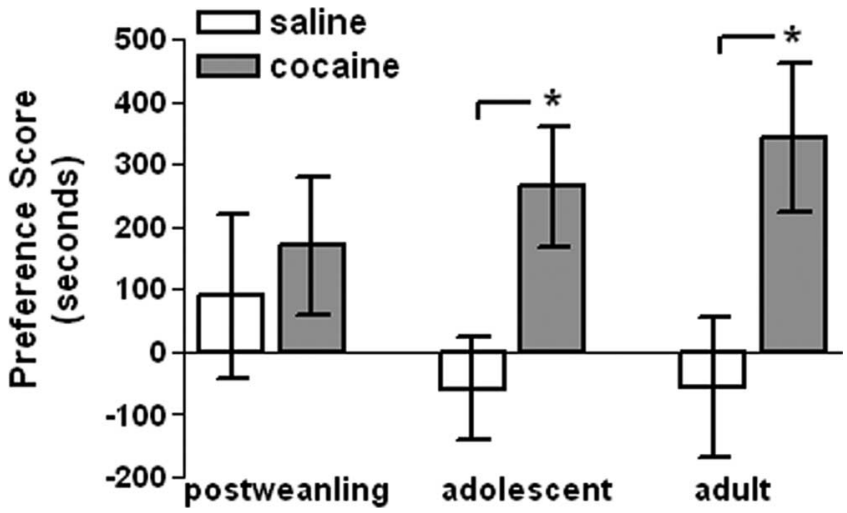

Figure 1. Cocaine-induced conditioned place preference in postweanling, periadolescent, and adult mice. Postweanling, periadolescent, and adult mice were conditioned with $20 \mathrm{mg} / \mathrm{kg}$ cocaine or saline using a $7 \mathrm{~d}$ conditioning paradigm. On test day 8, preference scores (time spent on cocaine-conditioned side minus time spent on saline-conditioned side) were determined. Cocaine produced a significant place preference in periadolescent and adult, but not postweanling CD-1 mice (saline vs cocaine, ${ }^{*} p<0.05$ ). Data are represented as mean \pm SEM (cocaine, $n=16$ postweanling, $n=8$ periadolescent, $n=7$ adult; saline, $n=8$ all ages).

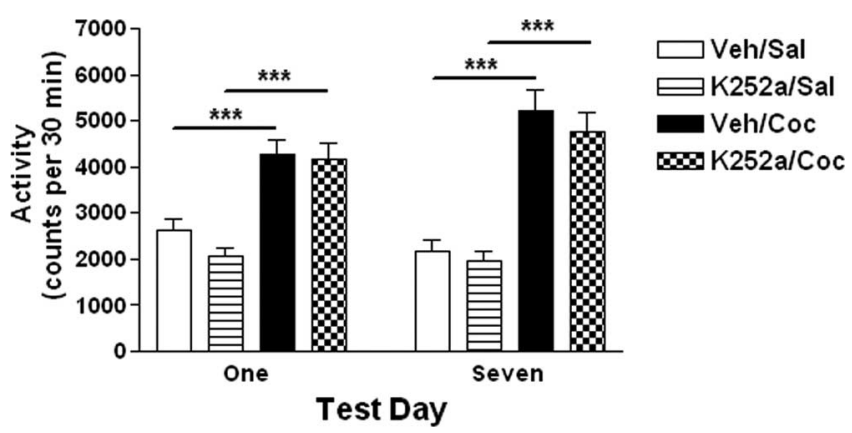

Figure 2. Effect of the Trk receptor antagonist K252a on cocaine-induced activity in postweanling mice. Postweanling mice were pretreated daily with vehicle or K252a (i.c.v.) 30 min before saline or cocaine $(20 \mathrm{mg} / \mathrm{kg}$, i.p.) for $7 \mathrm{~d}$. Activity was measured for $30 \mathrm{~min}$ after the saline or cocaine injections on days 1 and 7 of the study. Mice injected with cocaine had higher activity counts than those injected with saline on both days, regardless of the pretreatment $\left(^{* * *} p<\right.$ 0.001). Pretreatment with K252a did not alter baseline or cocaine-induced activity on either days 1 or 7 . Activity on days 1 and 7 were not significantly different for any treatment group. Data are expressed as mean \pm SEM ( $n=9-12 /$ group).

\section{Cocaine-induced sensitization and conditioned place} preference in postweanling mice pretreated with $\mathrm{K} 252 \mathrm{a}$ Based on the important role of the BDNF/TrkB system during development and in responses to psychostimulants in adults (Yurek et al., 1998; Horger et al., 1999), we investigated whether age-dependent responses to cocaine may rely on an intact neurotrophic system. Postweanling mice were pretreated with either vehicle or K252a, a Trk receptor antagonist, 30 min before daily injections of cocaine (20 mg/kg, i.p.) or saline for $7 \mathrm{~d}$. Figure 2 shows total activity on days 1 and 7 of the study. On both test days, the activity of the cocaine-injected animals was significantly greater than the activity of those injected with saline regardless of the pretreatment (day $1, F_{(3,44)}=18.55, p<0.0001$; day $7, F_{(3,44)}$ $=27.72, p<0.001$ ). There were no differences between activity counts on days 1 and 7 in either of the cocaine treatment groups, indicating that there was no development of behavioral sensitization. This agrees with our previous studies in CD-1 postweanling mice (Niculescu et al., 2005). Daily pretreatment with K252a did not alter cocaine-induced activity on day 1 or day 7 (Fig. 2). These data imply that blockade of Trk receptors does not play a signif- 


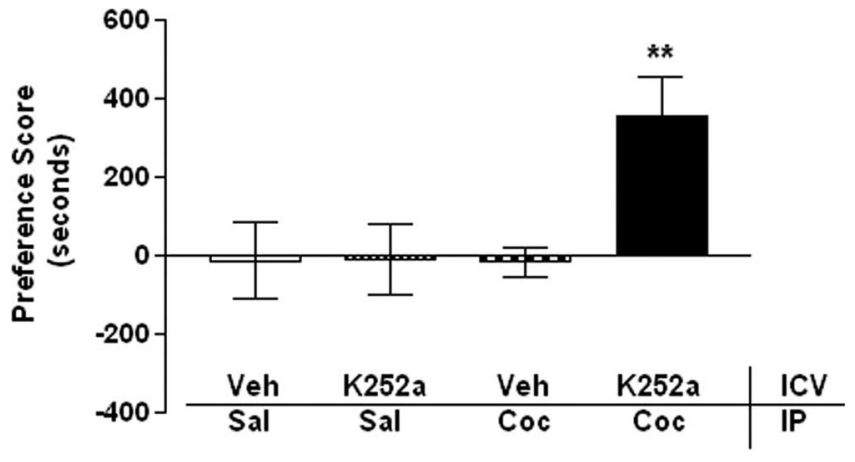

Figure 3. Effect of the Trk receptor antagonist, K252a, on cocaine-conditioned place preference in postweanling mice. Postweanling mice were pretreated with $\mathrm{K} 252 \mathrm{a}$ or vehicle (i.c.v.) 30 min before being conditioned with cocaine $(20 \mathrm{mg} / \mathrm{kg}$ ) or saline in a $7 \mathrm{~d}$ conditioning paradigm. On test day 8 , preference scores were determined in the absence of drug administration. Postweanling mice that received cocaine only (Veh, i.c.v. plus Coc, i.p.) did not show a significant place preference for the cocaine-paired environment. However, pretreatment with K252a before cocaine (K252a, i.c.v. plus $\mathrm{Coc}$, i.p.) on conditioning days $1-7$ resulted in a significant place preference to the cocaine-paired environment $\left({ }^{* *} p<0.01\right)$. Data are shown as mean \pm SEM $(n=9-12)$.

icant role in cocaine-induced activity or the lack of sensitization in postweanling mice.

In a similar manner, the ability of K252a to alter cocaine reward in postweanling mice was determined. The mean preference score for animals receiving K252a before cocaine (K252a/ Coc) was significantly different from the three other treatment groups (Fig. 3) (two-way ANOVA treatment, $F_{(1,36)}=47.39, p<$ 0.0001; pretreatment, $F_{(1,36)}=51.07, p<0.0001$; interaction, $\left.F_{(1,36)}=49.55, p<0.0001\right)$. Pretreatment with K252a significantly increased the rewarding effects of cocaine [Bonferroni's post-test K252a/Coc vs vehicle (Veh)/Coc, $p<0.001$ ]. Furthermore, postweanling mice pretreated with $\mathrm{K} 252 \mathrm{a}$ and conditioned with cocaine (K252a/Coc) showed a significant place preference for the cocaine-paired environment (one-sample $t$ test, $t_{(7)}=$ 3.533, $p<0.01$ ). Those pretreated with the vehicle followed by cocaine (Veh/Coc) did not show a significant place preference to the cocaine-paired environment $\left(t_{(11)}=0.42, p>0.05\right)$, in agreement with the data on cocaine alone in postweanling mice shown in Figure 1. Administration of K252a in conjunction with two saline conditioning sessions per day (K252a/Sal) produced neither a significant place preference nor place aversion $\left(t_{(9)}=0.11\right.$, $p>0.05)$. Thus, a Trk receptor antagonist increased the rewarding properties of cocaine in postweanling mice.

\section{Age-specific DARPP-32 mRNA regulation: in situ hybridization and Northern blot analysis}

Like BDNF, DARPP-32 is also a critical mediator of responses to psychostimulants (Zachariou et al., 2002), and previous studies have demonstrated that one of the few identified endogenous regulators of DARPP-32 expression in vivo is BDNF-mediated signaling via TrkB and phosphatidylinositide 3-kinase (PI3K) (Ivkovic and Ehrlich, 1999; Stroppolo et al., 2001). Therefore, we hypothesized that $\mathrm{TrkB}$ regulated age-dependent responses to psychostimulants also may be associated with age-specific regulation of DARPP-32 after cocaine. To test this hypothesis, we determined whether age-related differences in the rewarding properties of cocaine were associated with alterations in DARPP-32 expression. We measured levels of DARPP-32 mRNA using in situ hybridization in the nucleus accumbens and quadrants of the caudate-putamen in postweanling, periadolescent and adult mice exposed to cocaine or saline control. Chronic administration of cocaine $(20 \mathrm{mg} / \mathrm{kg})$ for $7 \mathrm{~d}$ had no significant effect on DARPP-32 mRNA levels in the nucleus accumbens (Fig. $4 A$ ) or rostral aspect of the caudate-putamen (Fig. $4 B, C$ ) in any age group (all $p>0.05$ ). However, chronic administration of cocaine resulted in a decrease in DARPP-32 mRNA expression in the lateral $\left(t_{(14)}=2.446 ; p<0.05\right)$ and medial $\left(t_{(14)}=2.854 ; p<\right.$ $0.05)$ portion of the caudal caudate-putamen exclusively in postweanling mice (Fig. $4 D, E$ ). This is the first demonstration of an alteration in DARPP-32 mRNA in the caudate-putamen after administration of a psychostimulant in any age group.

Northern blot analysis of DARPP-32 mRNA was used to confirm the findings from the in situ hybridization study. Again, levels of DARPP-32 mRNA in the lateral (Fig. 5A) and medial (Fig. $5 B$ ) rostral aspects of the caudate-putamen were not significantly different between saline and cocaine-exposed mice of any age group. Northern blot analysis confirmed a decrease in DARPP-32 mRNA expression levels in the lateral portion of the caudal caudate-putamen (Fig. $5 C$ ) after $7 \mathrm{~d}$ of cocaine in postweanling mice $\left(t_{(8)}=2.70 ; p<0.05\right)$. By Northern blotting, there were no differences in DARPP-32 mRNA expression in the medial portion of the caudal caudate-putamen after chronic exposure to cocaine in any of the age groups (Fig. 5D).

\section{Age-specific DARPP-32 protein regulation}

We next determined whether DARPP-32 protein levels were similarly regulated relative to its $\mathrm{mRNA}$. DARPP-32 mRNA and protein were simultaneously extracted from individual brain samples. DARPP-32 protein levels were not significantly different in the nucleus accumbens core or shell (Fig. $6 A, B$ ), rostral caudateputamen (Fig. $6 C, D$ ), or medial aspect of the caudal caudateputamen (Fig. $6 F$ ) of cocaine-injected animals from any age group compared with saline-injected age-matched controls. In postweanling mice, chronic administration of cocaine resulted in a significant increase in DARPP-32 levels in the lateral caudal caudate-putamen compared with saline-injected controls (Fig. $6 E)\left(t_{(11)}=2.612 ; p<0.05\right)$. This was not seen in the older age groups. These results indicate that DARPP-32 protein levels are significantly upregulated in the lateral caudal caudate-putamen of postweanling mice exposed to cocaine (Fig. 6E), whereas DARPP-32 mRNA levels are significantly downregulated in the same area (Figs. 4D, 5C).

\section{Time course of DARPP-32 regulation in the lateral caudal caudate-putamen of postweanling mice during cocaine exposure}

To begin to investigate the dissociation of DARPP-32 mRNA and protein, the time course of regulation of the two was characterized in tissue from the caudal caudate-putamen. Saline or cocaine $(20 \mathrm{mg} / \mathrm{kg})$ was administered to postweanling mice for 1,4 , or $7 \mathrm{~d}$, and tissues were obtained $18 \mathrm{~h}$ after the final injection. DARPP-32 mRNA and protein were not significantly altered after a single injection of cocaine, although mRNA levels were reduced by $29.1 \%$ (Fig. 7). After $4 \mathrm{~d}$ of cocaine exposure, DARPP-32 mRNA levels were reduced by $37.5 \%$ and DARPP-32 protein levels were increased by $62.8 \%$, albeit these differences also did not reach statistical significance. After $7 \mathrm{~d}$ of cocaine administration, DARPP-32 mRNA was significantly reduced by $52.2 \%(p<0.05)$ and protein was increased by $110 \%(p<0.05)$. Thus, we conclude that there is a gradual decrease in DARPP-32 mRNA starting after only a single dose of cocaine, which is accompanied by a gradual increase in protein. The prolonged time course precluded the use of protein synthesis inhibitors and/or 
metabolic labeling to determine the exact mechanism of regulation of protein levels.

Attenuation of the cocaine-induced alterations in DARPP-32 by the Trk receptor antagonist K252a

To test the relationship between Trk activation and cocaine-induced DARPP-32 protein upregulation, the levels of the latter were measured in postweanling mice that were pretreated with the Trk receptor antagonist K252a before daily cocaine administration. Two-way ANOVA indicates significant effects of treatment and pretreatment (treatment, $F_{(1,36)}=6.04, p<$ 0.05 ; pretreatment, $F_{(1,36)}=4.43, p<$ 0.05 ; interaction, $\left.F_{(1,36)}=2.78, p>0.05\right)$ on DARPP-32 levels. In agreement with the results presented from noncannulated mice (Fig. $6 E$ ), postweanling animals pretreated with vehicle intracerebroventricularly followed by daily cocaine showed a significant upregulation in DARPP-32 levels in the lateral portion of the caudal caudate-putamen (Fig. 8) (Bonferroni's post hoc comparison Veh/Sal vs Veh/Coc, $p<0.05)$. The cocaine-induced increase in DARPP-32 was significantly attenuated by pretreatment with $\mathrm{K} 252 \mathrm{a}$ (Veh/Coc vs $\mathrm{K} 252 \mathrm{a} / \mathrm{Coc}, p<0.05)$. Thus, blockade of Trk receptors before cocaine administration prevented the induction of DARPP-32 protein and induced the development of cocaine conditioned place preference in postweanling mice. K252a alone or in conjunction with cocaine had no effect on DARPP-32 levels in the nucleus accumbens, medial caudal caudate-putamen or rostral caudate-putamen (data not shown).

\section{Levels of phospho-DARPP-32 in} postweanling mice

The active form of DARPP-32 is phosphorylated at $\mathrm{Thr}^{34}$, and a mutation at this site attenuates the development of cocaine place preference ( $\mathrm{Za}$ chariou et al., 2006). We therefore sought to determine whether postweanlings and adults differ in the levels of phosphoDARPP-32 in the striatum. We first confirmed (Ehrlich et al.,1990) in CD-1 mice that baseline levels of total DARPP-32 are approximately equal at these ages and that a single injection of cocaine did not alter total DARPP-32 levels in either age group (Fig. 9A) (two-way ANOVA: age, $F_{(1,31)}=0.098$; treatment, $F_{(1,31)}=0.491$; interaction, $F_{(1,31)}=0.020$; all $p$ values $\left.>0.05\right)$. The levels of phosphoThr ${ }^{34}$-DARPP-32 after an acute injection of cocaine $(20 \mathrm{mg} / \mathrm{kg}$ i.p.) or saline were then measured. Two-way ANOVA with age and treatment factors shows a significant effect of age $\left(F_{(1,31)}=29.52, p<0.0001\right)$, but not treatment $\left(F_{(1,31)}=1.450\right.$, $p>0.05)$ or interaction $\left(F_{(1,31)}=1.558, p>0.05\right)$ on the abundance of phosphoThr ${ }^{34}$-DARPP-32 (Fig. 9B). Baseline levels of phosphoThr ${ }^{34}$-DARPP-32 were markedly different between ages, with significantly lower levels of active phosphoThr ${ }^{34}$-DARPP-32 in postweanling mice compared with adults (Fig. 9B) (saline adult vs saline postweanling, $p<0.05)$. After a single injection of cocaine, levels of phosphoThr ${ }^{34}$-DARPP-32 in the adults increased by $\sim 32 \%$, whereas those in the postweanlings were identical to salineinjected controls (Fig. 9B). PhosphoThr ${ }^{34}$-DARPP-32 levels were significantly lower in postweanling mice after a cocaine injection than adult mice after the same treatment (cocaine adult vs cocaine postweanling, $p<0.001$ ). Notably, levels of phosphoThr ${ }^{75}$ DARPP-32 were identical in the two age groups and did not differ by treatment (Fig. 9C).

\section{Discussion}

In this study, the rewarding effects of cocaine were absent in postweanling mice under conditions that induced a significant place preference in periadolescent and adult mice, similar to our previous finding of an absence of cocaine-induced locomotor sensitization in this age group (Niculescu et al., 2005). This paradigm of cocaine exposure also produced an increase in DARPP-32 protein in the lateral caudal caudate-putamen of postweanling, but not adults or periadolescent mice. Pretreat- 


\section{Rostral Caudate Putamen}
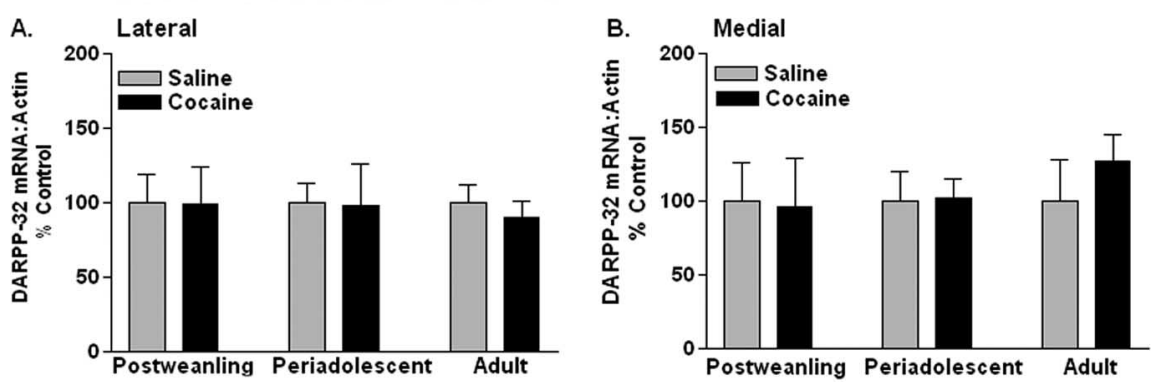

\section{Caudal Caudate Putamen}
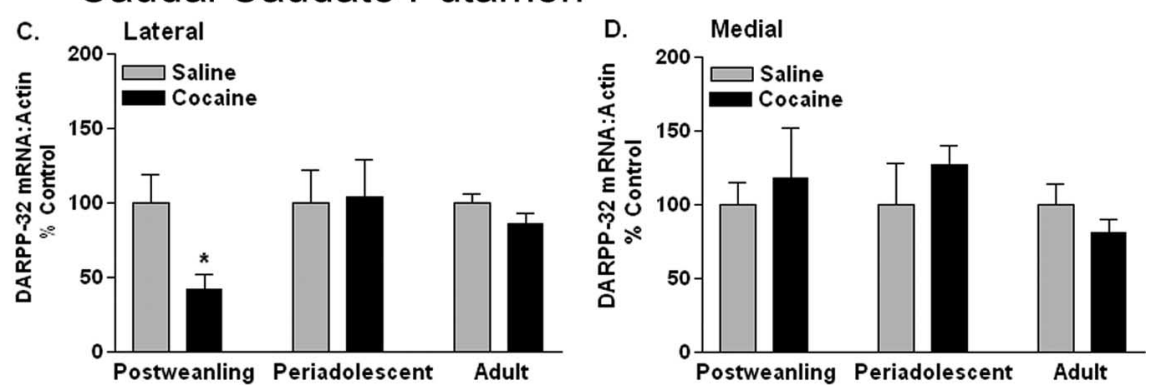

Figure 5. $A-D, D A R P P-32 m R N A$ in the caudate-putamen after cocaine administration as determined by Northern blot analyses. Mice were injected with $20 \mathrm{mg} / \mathrm{kg}$ cocaine or saline once daily for $7 \mathrm{~d}$. DARPP- $32 \mathrm{mRNA}$ was measured in tissue samples obtained $18 \mathrm{~h}$ after the last injection. In the lateral aspect of the caudal caudate-putamen, DARPP-32 mRNA levels were significantly lower in postweanling mice injected with cocaine than saline-injected controls of the same age (C). DARPP-32 mRNA levels in the $(\boldsymbol{A})$ lateral and $(\boldsymbol{B})$ medial aspects of the rostral caudate-putamen and medial aspect of the caudal caudate-putamen (D) were not altered after cocaine exposure in any age group. There were no differences in DARPP-32 levels between cocaine- and saline-injected periadolescent and adult mice in any brain region tested. Data are represented as a percentage of age-matched controls (mean $\pm \mathrm{SEM} ; n=6-8 ;{ }^{*} p<0.05$ postweanling saline vs postweanling cocaine).

ment with the Trk receptor antagonist, K252a, before daily cocaine induced a conditioned place preference in the postweanlings, and simultaneously prevented the increase in DARPP-32. This is one of only a limited number of investigations into the molecular underpinnings of age-related differential responses to psychostimulants, likely related to the increased plasticity of the brain during this period of extensive remodeling (Spear, 2000). Highly relevant to these studies is the literature documenting fluxes in levels of molecules identified as key mediators of cocaine's actions, including components of both the dopamine (Ehrlich et al., 1990; Tarazi et al., 1999) and neurotrophin BDNF (Ringstedt et al., 1993; Yurek et al., 1998; Costantini et al., 1999) pathways.

Previous studies have, in isolation, demonstrated a role for DARPP-32 or BDNF and its receptor, TrkB, in the behavioral response to cocaine (for review, see Bolanos and Nestler, 2004; Nairn et al., 2004), but have not shown concurrent modulation of the two systems. Thus, cocaine-induced conditioned place preference is reduced in adult DARPP-32-null mice (Zachariou et al., 2002), whereas locomotor sensitization is enhanced (Hiroi et al., 1999). BDNF microinjected into the accumbens or ventral tegmental area of adult rats increases cocaine seeking behaviors and behavioral sensitization (Horger et al., 1999; Lu et al., 2004; Graham et al., 2007), whereas BDNF infusion into the prefrontal cortex suppresses cocaine seeking (Berglind et al., 2007). These findings indicate that the ability of BDNF to modulate cocaineinduced behaviors is dependent on the brain region involved. Thus, the lack of cocaine reward in postweanling mice and its enhancement after K252a may suggest a relatively higher BDNF tone in the frontal cortex of young mice than adults, although it should be noted that K252a can block the effects of other neurotrophins at TrkA and TrkC receptors as well. In the striatum, TrkA is largely localized to cholinergic interneurons (Holtzman et al., 1992), and therefore unlikely to play a major role in our current observations. The potential involvement of neurotrophin-3 (NT-3) in cocaine-induced locomotor sensitization has been shown (Pierce et al., 1999). Thus, although the overwhelming evidence supports a role of BDNF/TrkB in the rewarding effects of cocaine, we cannot rule out a contribution from NT-3/TrkC.

Our results suggest that in postweanling mice activation of Trk receptors, likely by endogenous BDNF, reduces the rewarding effects of cocaine as pretreatment with K252a enhanced the development of cocaine place preference. Furthermore, repeated cocaine was associated with increased DARPP-32 protein in postweanlings and DARPP-32 induction was prevented with K252a. Together, these results suggest an association between BDNF, cocaine reward, and DARPP-32 in postweanling mice. Although inhibition of Trk clearly enhanced the acquisition of cocaine place preference and diminished the upregulation of DARPP-32, these data do not prove a direct cause and effect relationship between DARPP-32 levels and the absence or presence of a rewarding effect of cocaine. Furthermore, these data do not indicate whether postweanling mice are more or less sensitive to the rewarding properties of cocaine. Our previous studies demonstrate that postweanling mice are less sensitive to the locomotor-activating effects of cocaine at the dose used in the present study (Niculescu et al., 2005), however the two behaviors may dissociate as discussed below. Future studies will include a full dose-response experiment to resolve this issue.

Acute exposure to cocaine failed to increase the phosphorylation of DARPP-32 at the $\mathrm{Thr}^{34}$ site in the dorsal striatum of postweanling mice, consistent with previous results in brain slices (Fukui et al., 2003). However, because we saw only a 32\% increase in phosphoThr ${ }^{34}$-DARPP-32 after cocaine in simultaneously studied adult mice, it is difficult to make a firm conclusion as to whether these data are reflective of age and/or background strain (Sun et al., 2007). However, there were marked age-related differences in levels of phosphoThr ${ }^{34}$-DARPP-32 both at baseline and after a cocaine injection, despite equal total DARPP-32 levels. Although confirmation in mice is required, weanling rats display normal dopamine overflow in the dorsal striatum after cocaine (Cao et al., 2007). Therefore, the reduced activation of a signal transduction pathway downstream of dopamine may at least partially explain the failure of the postweanling mice to develop a significant place preference to cocaine. This situation is notably similar to that found in comparative studies between male and female rats, where female rats have higher levels of phosphoThr ${ }^{34}$-DARPP-32 and differential responses to cocaine (Lynch et al., 2007).

Chronic cocaine exposure in postweanling mice elevated total DARPP-32 protein while decreasing DARPP-32 mRNA in the 
caudal caudate-putamen. This appears to be the first example of post-transcriptional regulation of DARPP-32 protein levels. Because BDNF can stabilize proteins posttranslationally (Suzuki and Koike, 1997), it is possible that DARPP-32 protein is increased in postweanling mice because of Trk-mediated protein stabilization. BDNF also activates the mammalian target of rapamycin (mTOR) via PI3K (Schratt et al., 2004). mTOR is a major regulator of protein translation, and it is therefore also possible that this mechanism is contributing to the mRNA/protein dissociation.

Another important finding of this study is the restriction of elevation of DARPP-32 protein levels after repeated cocaine to the lateral portion of the caudal caudate-putamen of postweanling mice. Although cocaine-induced reinforcement has traditionally been associated with the ventral striatum (i.e., nucleus accumbens) (Koob, 1992; Wise and Hoffman, 1992), the dorsal striatum (i.e., caudate-putamen) has also been implicated in mediating aspects of cocaine reward. The dorsolateral caudateputamen, or sensorimotor striatum, has been identified as a mediator of stimulusresponse associations and implicated in habit learning (Mishkin et al., 1984; Jog et al., 1999). Previous theories of drug addiction suggest that as drug abuse progresses from an acquisition phase involving goaldirected learning to the compulsive habit formations that defines drug addiction, the involved neural circuits switch from the ventral striatum to one that is mediated predominantly by the dorsal striatum (Berke and Hyman, 2000; Everitt and Wolf, 2002; Gerdeman et al., 2003). In support of the role of the dorsal striatum in cocaineinfluenced behaviors, cocaine self-administration by primates activates the caudal caudate, and this response progressively increases with escalating cocaine exposure (Porrino et al., 2004). The caudate is also activated in human cocaine users during cocaine craving (Garavan et al., 2000). In rats, extracellular dopamine levels in the lateral caudate-putamen increase during cocaine-seeking behavior (Ito et al., 2002). Furthermore, the dorsal lateral caudate-putamen has been shown to be critical for cocaine seeking after abstinence (Fuchs et al., 2006). Willuhn et al. (2003) studied the topography of cocaine-induced gene regulation in rat striatum and found that the caudal dorsal caudateputamen is the site of maximal cocaine-induced c-fos and prodynorphin gene regulation.

The Trk receptor antagonist K252a reversed the behavioral phenotype of the absence of cocaine-induced place preference in postweanling mice; however, it did not affect behavioral sensitization, suggesting that Trk receptors, and perhaps DARPP-32, are differentially involved in mediating these two behaviors. Previous studies suggest that behavioral sensitization and conditioned place preference to cocaine are mediated by different mechanisms. For example, absence of DARPP-32 leads to heightened locomotor sensitization to repeated cocaine (Hiroi et al., 1999) and reduced cocaine reward (Zachariou et al., 2002). Furthermore, a mutation in the $\mathrm{Thr}^{75}$ residue of DARPP-32 eliminates locomotor sensitization, but has no effect on place preference (Zachariou et al., 2006).

Projecting from the studies in the adult DARPP-32-null mouse, the increase in DARPP-32 in the postweanling mouse might have been predicted to be accompanied by enhanced development of cocaine-induced place preference. One possible explanation for this apparent discrepancy is that there are multiple adaptive alterations in the DARPP-32-null mouse that are unlikely to be present in our mice (Hiroi et al., 1999). It may also be the case that the abundance of phosphoThr ${ }^{34}$ DARPP-32, which is significantly lower in the young animals, is more important than levels of total DARPP-32 in this regard. These data reinforce the notion that findings from adult subjects of any species cannot automatically be extrapolated to younger subjects.

In conclusion, this is the first study to suggest an association of the striatal BDNF/TrkB system in the neurodevelopmental responses to psychostimulants. Our findings indicate that Trk receptor signal transduction mediates the "normal" behavioral response of postweanling mice to repeated cocaine exposure, and that Trk plays an important role in cocaine-induced DARPP-32 induction in this age group. Furthermore, these data provide evidence for the theory that the immature nervous system is primed for heightened neuroplasticity resulting in neuroprotec- 


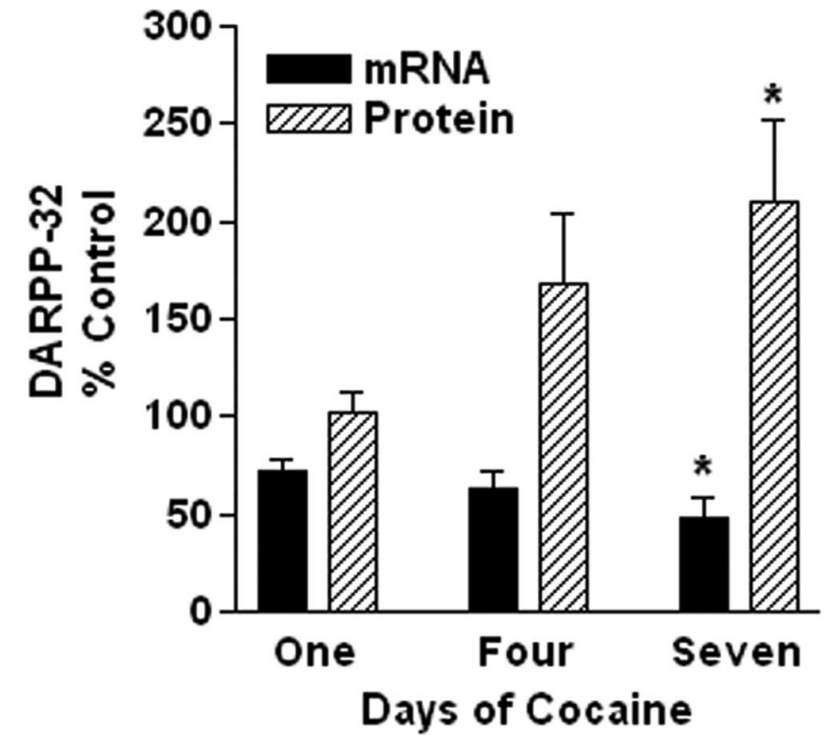

Figure 7. Time course of DARPP- $32 \mathrm{mRNA}$ and protein regulation in the lateral aspect of the caudal caudate-putamen of postweanling mice after cocaine administration. Postweanling, periadolescent, and adult mice were injected with saline or cocaine $(20 \mathrm{mg} / \mathrm{kg})$ daily for 1,4 , or $7 \mathrm{~d}$. DARPP-32 mRNA was measured by Northern blot analysis and DARPP-32 protein was measured by Western blot analysis in the same tissue samples, which were obtained $18 \mathrm{~h}$ after the last injection. DARPP-32 mRNA gradually declined over the $7 \mathrm{~d}$ of cocaine administration, whereas DARPP-32 protein increased over the same time period. Data are expressed as a percentage of DARPP-32 mRNA:actin mRNA or DARPP-32 protein:tubulin in saline-injected control mice (mean \pm SEM, $n=6-8 ;{ }^{*} p<0.05$ cocaine vs saline).

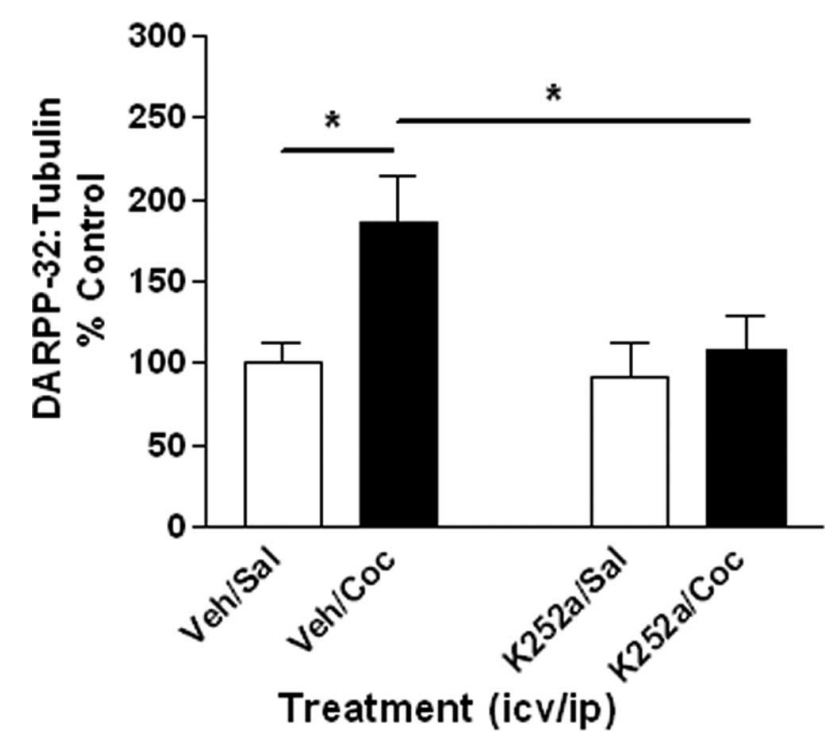

Figure 8. Effects of the Trk receptor antagonist on DARPP-32 levels in the lateral caudal caudate-putamen. Postweanling mice were pretreated with K252a or vehicle intracerebroventricularly $30 \mathrm{~min}$ before $20 \mathrm{mg} / \mathrm{kg}$ cocaine or saline i.p. for $7 \mathrm{~d}$. DARPP-32 immunoreactivity was measured in the lateral caudal caudate-putamen in tissue samples obtained $18 \mathrm{~h}$ after the last injection. Postweanling mice that received cocaine alone (Veh/Coc) had significantly higher levels of DARPP-32 in the lateral caudal caudate-putamen than control mice (Veh/Sal). Pretreatment with the Trk receptor antagonist K252a prevented cocaine-induced upregulation of DARPP-32 (Veh/Coc vs K252a/Coc; mean \pm SEM; $n=8-10 /$ group; ${ }^{*} p<0.05$ ).

tion against the rewarding effects of cocaine and simultaneously may suggest that this pathway be explored for therapeutic approaches to both addiction and childhood neuropsychiatric disease.
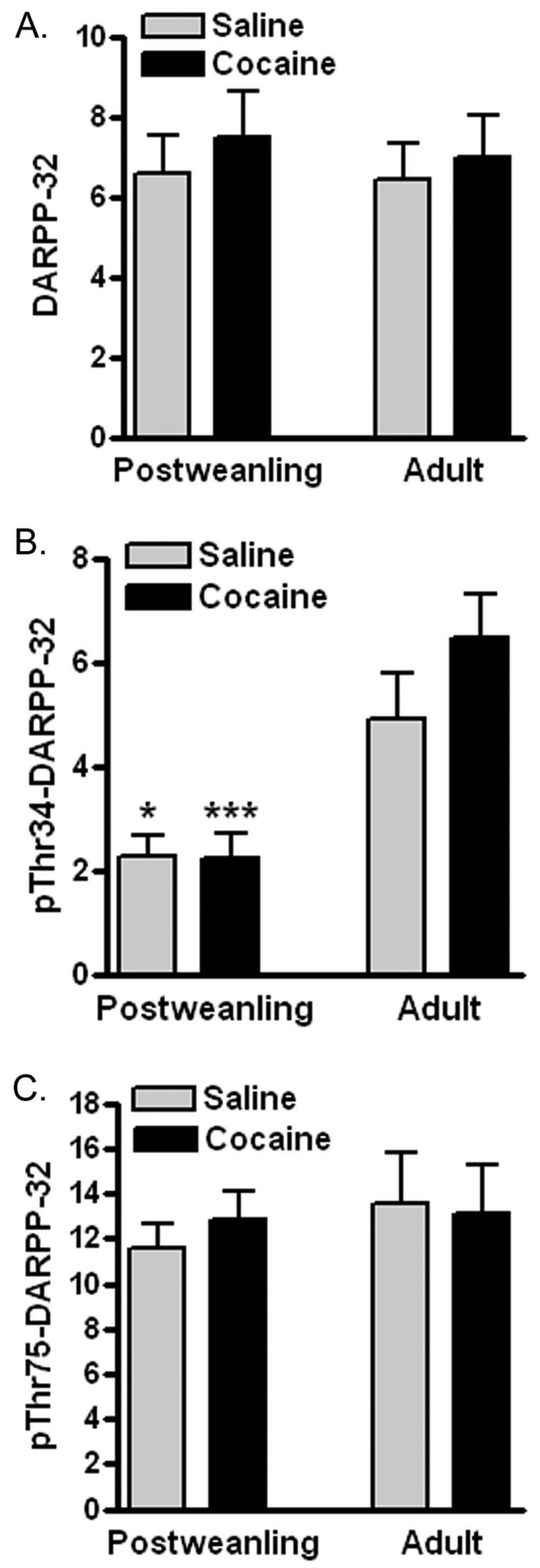

Figure 9. Phosphorylation of DARPP-32 in the striatum of postweanling and adult mice. Postweanling and adult mice received a single injection of saline or cocaine $(20 \mathrm{mg} / \mathrm{kg})$ and striatum was obtained 15 min postinjection. $A-C$, Levels of total DARPP-32 (A), phosphoThr ${ }^{34}$ DARPP-32 $(\boldsymbol{B})$, and phosphoThr ${ }^{75}$-DARPP-32 (C) were measured by Western blot. PhosphoThr ${ }^{34}$-DARPP-32 was significantly lower in postweanling mice compared with adults both at baseline and after a cocaine injection $(\boldsymbol{B})\left({ }^{*} p<0.05\right.$, postweanling saline vs adult saline; ${ }^{* * *} p<0.001$, postweanling cocaine vs adult cocaine). Data are expressed as the mean \pm SEM of the ratio of DARPP-32:tubulin in arbitrary units ( $n=8-10 /$ group). 


\section{References}

Altar CA, Boylan CB, Jackson C, Hershenson S, Miller G, Wiegand NJ, Lindsay RM, Hyman C (1992) Brain-derived neurotrophic factor augments rotational behavior and nigrostriatal dopamine turnover. Proc Natl Acad Sci USA 89:11347-113551.

Andersen SL (2002) Changes in the second messenger cyclic AMP during development may underlie motoric symptoms in attention deficit/hyperactivity disorder (ADHD). Behav Brain Res 130:197-201.

Andersen SL, Teicher MH (2000) Sex differences in dopamine receptors and their relevance to ADHD. Neurosci Biobehav Rev 24:137-141.

Bardo RA, Bevins MT (2000) Conditioned place preference: what does it add to our preclinical understanding of drug reward? Psychopharmacology (Berl) 153:31-43.

Berke JD, Hyman SE (2000) Addiction, dopamine, and the molecular mechanisms of memory. Neuron 25:515-532.

Berglind WJ, See RE, Fuchs RA, Ghee SM, Whitfield Jr TW, Miller SW, McGinty JF (2007) A BDNF infusion into the medial prefrontal cortex suppresses cocaine seeking in rats. Eur J Neurosci 26:757-766.

Bibb JA, Chen J, Taylor JR, Svenningsson P, Nishi A, Snyder GL, Yan Z, Sagawa ZK, Ouimet CC, Nairn AC, Nestler EJ, Greengard P (2001) Effects of chronic exposure to cocaine are regulated by the neuronal protein Cdk5. Nature 410:376-380.

Bolanos CA, Nestler EJ (2004) Neurotrophic mechanisms in drug addiction. Neuromolecular Med 5:69-83.

Campbell JO, Wood RD, Spear LP (2000) Cocaine and morphine-induced place conditioning in adolescent and adult rats. Physiol Behav 68:487-493.

Cao J, Lotfipour S, Loughlin SE, Leslie FM (2007) Adolescent maturation of cocaine-sensitive neural mechanisms. Neuropsychopharmacology 32:2279-2289.

Cirulli F, Laviola G (2000) Paradoxical effects of D-amphetamine in infant and adolescent mice: role of gender and environmental risk factors. Neurosci Biobehav Rev 24:73-84.

Collins SL, Izenwasser S (2002) Cocaine differentially regulates both behavior and neurochemistry in periadolescent versus adult rats. Brain Res Dev Brain Res 138:27-34.

Costantini LC, Feinstein SC, Radeke MJ, Snyder-Keller A (1999) Compartmental expression of TrkB receptor protein in developing striatum. Neuroscience 89:505-513.

DiChiara G, Imperato A (1988) Drugs abused by humans preferentially increase synaptic dopamine concentrations in the mesolimbic system of freely moving rats. Proc Natl Acad Sci USA 85:5274-5278.

Ehrlich ME, Rosen NL, Kurihara T, Shalaby IA, Greengard P (1990) DARPP-32 development in the caudate nucleus is independent of afferent input from the substantia nigra. Brain Res Dev Brain Res 54:257-263.

Ehrlich ME, Sommer J, Canas E, Unterwald EM (2002) Periadolescent mice show enhanced DeltaFosB upregulation in response to cocaine and amphetamine. J Neurosci 22:9155-9159.

Everitt BJ, Wolf ME (2002) Psychomotor stimulant addiction: a neural systems perspective. J Neurosci 22:3312-3320.

Fishman M, Bruner A, Adger Jr H (1997) Substance abuse among children and adolescents. Pediatrics Rev 18:394-403.

Fuchs RA, Branham RK, See RE (2006) Different neural substrates mediate cocaine seeking after abstinence versus extinction training: a critical role for the dorsolateral caudate-putamen. J Neurosci 26:3584-3588.

Fukui R, Svenningsson P, Matsuishi T, Higashi H, Nairn AC, Greengard P, Nishi A (2003) Effect of methylphenidate on dopamine/DARPP signaling in adult, but not young, mice. J Neurochem 87:1391-1401.

Garavan H, Pankiewicz J, Bloom A, Cho JK, Sperry L, Ross TJ, Salmeron BJ, Risinger R, Kelley D, Stein EA (2000) Cue-induced cocaine craving: neuroanatomical specificity for drug users and drug stimuli. Am J Psychiatry 157:1789-1798.

Gerdeman GL, Partridge JG, Lupica CR, Lovinger DM (2003) It could be habit forming: drugs of abuse and striatal synaptic plasticity. Trends Neurosci 26:184-192.

Graham DL, Edwards S, Bachtell RK, DiLeone RJ, Rios M, Self DW (2007) Dynamic BDNF activity in the nucleus accumbens with cocaine use increases self-administration and relapse. Nat Neurosci 10:1029-1037.

Hemmings HC, Greengard P, Tung HY, Cohen P (1984) DARPP-32, a dopamine-regulated neuronal phosphoprotein, is a potent inhibitor of protein phosphatase-1. Nature 310:503-505.

Hiroi N, Fienberg AA, Haile CN, Alburges M, Hanson GR, Greengard P,
Nestler EJ (1999) Neuronal and behavioural abnormalities in striatal function in DARPP-32-mutant mice. Eur J Neurosci 11: $1114-1118$.

Holtzman DM, Li Y, Parada LF, Kinsman S, Chen CK, Valletta JS, Zhou J, Long JB, Mobley WC (1992) p140trk mRNA marks NGF-responsive forebrain neurons: evidence that trk gene expression is induced by NGF. Neuron 9:465-478.

Horger BA, Iyasere CA, Berhow MT, Messer CJ, Nestler EJ, Taylor JR (1999) Enhancement of locomotor activity and conditioned reward to cocaine by brain-derived neurotrophic factor. J Neurosci 19:4110-4122.

Ito R, Dalley JW, Robbins TW, Everitt BJ (2002) Dopamine release in the dorsal striatum during cocaine-seeking behavior under the control of a drug-associated cue. J Neurosci 22:6247-6253.

Ivkovic S, Ehrlich ME (1999) Expression of the striatal DARPP- 32/ ARPP-21 phenotype in GABAergic neurons required neurotrophins in vivo and in vitro. J Neurosci 19:5409-5419.

Ivkovic S, Polonskaia O, Farinas I, Ehrlich ME (1997) Brain-derived neurotrophic factor regulates maturation of the DARPP-32 phenotype in striatal medium spiny neurons: studies in vivo and in vitro. Neuroscience 79:509-516.

Jog MS, Kubota Y, Connolly CI, Hillegaart V, Graybiel AM (1999) Building neural representations of habits. Science 286:1745-1749.

Koob GF (1992) Neural mechanism of drug reinforcement. Ann NY Acad Sci 654:171-191.

Laviola G, Dell'Omo G, Alleva E, Bifnami G (1992) Ontogeny of cocaine hyperactivity and conditioned place preference in mice. Psychopharmacology 107:221-228.

Laviola G, Dell'Omo G, Chiarotti G, Bignami G (1994) d-Amphetamine conditioned place preference in developing mice: relations with changes in activity and stereotypies. Behav Neurosci 108:514-524.

Laviola G, Adriani W, Terranova ML, Gerra G (1999) Psychobiological risk factors for vulnerability to psychostimulants in human adolescent and adult animals. Neurosci Biobehav Rev 23:993-1010.

Lu L, Dempsey J, Liu SY, Bossert JM, Shaham Y (2004) A single infusion of brain-derived neurotrophic factor into the ventral tegmental area induces long-lasting potentiation of cocaine seeking after withdrawal. J Neurosci 18:1604-1611.

Lynch WJ, Kiraly DD, Caldarone BJ, Picciotto MR, Taylor JR (2007) Effect of cocaine self-administration on striatal PKA-regulated signaling in male and female rats. Psychopharmacology 191:263-271.

Mishkin M, Malamut B, Bachevalier J (1984) Memories and habits: two neural systems. In: Neurobiology of human learning and memory (Lynch G, McGaugh JL, Weinberger NM, eds), pp 65-77. New York: Guilford.

Nairn AC, Svenningsson P, Nishi A, Fisone G, Girault JA, Greengard P (2004) The role of DARPP-32 in the actions of drugs of abuse. Neuropharmacology 47 [Suppl 1]:14-23.

Niculescu M, Ehrlich ME, Unterwald EM (2005) Age-specific behavioral responses to psychostimulants in mice. Pharm Biochem Behav $82: 280-288$.

Nishi A, Bibb JA, Snyder GL, Higashi H, Nairn AC, Greengard P (2000) Amplification of dopaminergic signaling by a positive feedback loop. Proc Natl Acad Sci USA 97:12840-12845.

Paxinos G, Franklin KB (2001) The mouse brain in stereotaxic coordinates, Ed 2. New York: Academic.

Pierce RC, Pierce-Bancroft AF, Prasad BM (1999) Neurotrophin-3 contributes to the initiation of behavioral sensitization to cocaine by activating the Ras/Mitogen-activated protein kinase signal transduction cascade. J Neurosci 19:8685-8695.

Porrino LJ, Lyons D, Smith HR, Daunais JB, Nader MA (2004) Cocaine self-administration produces a progressive involvement of limbic, association, and sensorimotor striatal domains. J Neurosci 24: $3554-3562$.

Rapoport JL, Buchsbaum MS, Weingartner H, Zahn TP, Ludlow C, Mikkelsen EJ (1980) Dextroamphetamine. Its cognitive and behavioral effects in normal and hyperactive boys and normal men. Arch Gen Psychiatry 37:933-943.

Rattiner LM, Davis M, French CT, Ressler KJ (2004) Brain-derived neurotrophic factor and tyrosine kinase receptor B involvement in amygdaladependent fear conditioning. J Neurosci 24:4796-4806.

Ringstedt T, Lagercrantz H, Persson H (1993) Expression of members of the Trk family in the developing postnatal rat brain. Brain Res Dev Brain Res 72:119-131. 
Schramm-Sapyta NL, Pratt AR, Winder DG (2004) Effects of periadolescent versus adult cocaine exposure on cocaine conditioned place preference and motor sensitization in mice. Psychopharmacology 173:41-48.

Schratt GM, Nigh EA, Chen WG, Hu L, Greenberg ME (2004) BDNF regulates the translation of a select group of mRNAs by a mammalian target of rapamycin-phosphatidylinositol 3-kinase-dependent pathway during neuronal development. J Neurosci 24:7366-7377.

Spear LP (2000) The adolescent brain and age-related behavioral manifestations. Neurosci Biobehav Rev 24:417-463.

Stroppolo A, Guinea B, Tian C, Sommer J, Ehrlich ME (2001) Role of phosphatidylinositide 3-kinase in brain-derived neurotrophic factor-induced DARPP-32 expression in medium size spiny neurons in vitro. J Neurochem 79:1027-1032.

Sun WL, Zhou L, Hazim R, Quinones-Jenab V, Jenab S (2007) Effects of acute cocaine on ERK and DARPP-32 phosphorylation pathways in the caudate-putamen of Fischer rats. Brain Res 1178:12-19.

Suzuki K, Koike T (1997) Brain-derived neurotrophic factor suppresses programmed cell death of cerebellar granule cells through a posttranslational mechanism. Mol Chem Neuropathol 30:101-124.

Tarazi FI, Tomasini EC, Baldessarini RJ (1999) Postnatal development of dopamine D1-like receptors in rat cortical and striatolimbic brain regions: an autoradiographic study. Dev Neurosci 21:43-49.

Tirelli E, Laviola G, Adriani W (2003) Ontogenesis of behavioral sensitization and conditioned place preference induced by psychostimulants in laboratory rodents. Neurosci Biobehav Rev 27:163-178.

Willuhn I, Sun W, Steiner H (2003) Topography of cocaine-induced gene regulation in the rat striatum: relationship to cortical inputs and role of behavioral context. Eur J Neurosci 17:1053-1066.

Wise RA, Hoffman DC (1992) Localization of drug reward mechanisms by intracranial injections. Synapse 10:247-263.

Yurek DM, Hipkens SB, Wiegand SJ, Altar CA (1998) Optimal effectiveness of BDNF for fetal nigral transplants coincides with the ontogenic appearance of BDNF in the striatum. J Neurosci 18:6040-6047.

Zachariou V, Benoit-Marand M, Allen PB, Ingrassia P, Fienberg AA, Gonon F, Greengard P, Picciotto MR (2002) Reduction of cocaine place preference in mice lacking the protein phosphatase 1 inhibitors DARPP 32 or Inhibitor 1. Biol Psychiatry 51:612-620.

Zachariou V, Sgambata-Faure V, Sasaki T, Svenningsson P, Berton O, Fienberg AA, Nairn AC, Greengard P, Nestler EJ (2006) Phosphorylation of DARPP-32 at threonine-34 is required for cocaine action. Neuropsychopharmacology 31:555-562. 